\section{Dr. H. J. Walke}

Dr. HAROLD WALKE died in Liverpool on December 21 from the effects of an electrical shock received while working in the Physics Laboratory of the University. He was twenty-eight years of age.

Dr. Walke was educated at the Plymouth Corporation Grammar School and University College, Exeter. He early developed an interest in the growing subject of nuclear physics, and he published. in quick succession a number of papers and notes which, while perhaps speculative and uncritical, revealed a fertile mind and a very fresh enthusiasm. In 1935 he was awarded a Commonwealth Fund fellowship and this gave him his first opportunity for experimental work in nuclear physics. $\mathrm{He}$ proceeded to the Radiation Laboratory, Berkeley, where he worked for two years under the direction of Prof. E. O. Lawrence. [Dr. Walke appears in the illustration of one of the Berkeley cyclotrons on p. 126 of this issue.] He published a number of excellent papers on artificial radioactivity produced in elements from potassium to vanadium.

Walke returned to Great Britain in 1937 to work in the Physics Laboratory, Liverpool, and in 1938 he was awarded an 1851 Exhibition senior studentship. He helped in the construction and operation of the cyclotron and, in addition, he continued his investigations into the activities induced in scandium, titanium and neighbouring elements, making some interesting discoveries in connexion with nuclear isomers and with the process of electron capture. $\mathrm{He}$ spent the summer of 1939 in Berkeley and returned in December with much work in hand and full of plans for the future. He had before him a career rich in promise, and his death at so early an age is a great loss to physics. Friendly and unassuming in manner, yet full of a vigorous and burning enthusiasm for his work, Walke was a delightful colleague. He is mourned by many friends both here and in the United States.

\section{Mr. Douglas H. Baird, C.B.E.}

$\mathrm{D}^{\mathrm{o}}$ OUGLAS HERIOT BAIRD, managing director of Messrs. Baird and Tatlock (London), Ltd., died on January 3, at fifty-six years of age. The direction of such a business implies a wide knowledge of laboratory practice and of scientific progress. Mr. Baird was well endowed in these respects by virtue of education at Charterhouse, University of London and Karlsruhe (under Engler), and also by twenty-seven years' experience in the business, nineteen in succession to his father, the late Mr. Hugh Harper Baird, who founded it in 1879.

The business being world-wide, Mr. Baird travelled extensively-Canada, the United States, India, Ceylon, Burma, etc.--believing that requirements peculiar to overseas trade can only be properly satisfied by an intimate acquaintance with the local conditions. In these countries, and in those of Europe, Mr. Baird had many friends, and it is safe to say that he met at one time or the other almost every well-known director of a laboratory. During the War of 1914-18, Mr. Baird, besides running a poison gas filling factory, did important work in connexion with field laboratories. $\mathrm{He}$ designed the first mobile bacteriological laboratory sent out to France, and was responsible for the improvements in this, and the planning of other special laboratories for the use of the Army Medical Service of the Allies. He was created a Commander of the Order of the British Empire for his services.

After the War, Messrs. Baird and Tatlock became associated with Messrs. Hopkin and Williams, Ltd. A complete new series of the well-known catalogues were issued and the works at Walthamstow were rebuilt. During the past year a six-story annex to their warehouses in Cross Street, Hatton Garden, E.C. has been erected. One floor of the new building is occupied by laboratories of the company's own design and construction.

The work carried out in these laboratories comprises the testing of apparatus, chemicals and materials for laboratory construction; preparation of standard solutions, microseopic stains, indicators, and special reagents; research in chemical manufacturing methods; and the preparation of some of the rarer chemicals (chiefly organic). Special attention is being devoted to the last-named section, which has already turned out a large number of new products, some of which have not previously been obtainable in Great Britain.

Last year a new branch of the firm was opened in Calcutta to deal with increasing trade in the East, and in England the Hopkin and Williams' chemical side has been developed by building two research laboratories in Cross Street, and one semi-industrial research laboratory which is a liaison between the investigating laboratory and the work for elaboration of new processes.

Mr. Baird was chairman of the British Chemical Ware Manufacturers' Association, this year being his twelfth in office, and a member of the Standards Committee of the Institute of Chemistry, and of a number of other bodies associated with scientific affairs and apparatus.

WE regret to announce the following deaths :

Mr. J. E. Dowson, known for his work in connexion with producer gas, on January 3, aged ninety-five years.

Prof. L. Hopf, professor of applied mathematics in the University of Aachen until 1933, on December 21.

M. Max Laubeuf, member of the Section of the Applications of Science to Industry of the Paris Academy of Sciences, a pioneer in the development of the modern submarine, aged seventy.five years.

Mr. Reginald A. Smith, keeper of the Department of British and Medieval Antiquities in the British Museum during 1927-38 and director of the Society of Antiquaries, on January 18, aged sixty-six years. 